\title{
Monasticism-Then and Now
}

\author{
John Binns
}

check for

updates

Citation: Binns, John. 2021. Monasticism-Then and Now. Religions 12: 510. https://doi.org/ 10.3390/rel12070510

Academic Editors: Bradley Nassif, Tim Grass and Greg Peters

Received: 30 April 2021

Accepted: 29 June 2021

Published: 8 July 2021

Publisher's Note: MDPI stays neutral with regard to jurisdictional claims in published maps and institutional affiliations.

Copyright: (C) 2021 by the author. Licensee MDPI, Basel, Switzerland. This article is an open access article distributed under the terms and conditions of the Creative Commons Attribution (CC BY) license (https:// creativecommons.org/licenses/by/ $4.0 /)$.
Centre of World Christianity, SOAS University of London, London WC1H 0XG, UK; Jb344@cam.ac.uk

\begin{abstract}
The monastic tradition has its roots in the New Testament practices of withdrawing into the desert, following a celibate lifestyle and disciplines of fasting. After the empire became Christian in the 4th century these ascetic disciplines evolved into monastic communities. While these took various forms, they developed a shared literature, gained a recognised place in the church, while taking different ways of life in the various settings in the life of the church. Western and Eastern traditions of monastic life developed their own styles of life. However, these should be recognised as being formed by and belonging to the same tradition, and showing how it can adapt to specific social and ecclesiastical conditions. In the modern world, this monastic way of life continues to bring renewal to the church in the 'new monasticism' which adapts traditional monastic practices to contemporary life. New monastic communities engage in evangelism, serve and identify with the marginalised, offer hospitality, and commit themselves to follow rules of life and prayer. Their radical forms of discipleship and obedience to the gospel place them clearly within the continuing monastic tradition.
\end{abstract}

Keywords: monk; asceticism-monastic life; community-desert; celibacy; fasting; common life; spirituality

\section{New and Old Monasticism}

The phrase 'new monasticism' has entered into theological vocabulary during the last fifty years. It covers a wide range of communities, practices, writings and movements which all recognize that they belong in some way to the tradition of monasticism. New forms of community life are found in all parts of the church. These new communities not only challenge and critique of modern secular culture, but also live out a renewed vision of the Christian gospel. They also enable a fresh assessment of monasticism, seeing it as rooted in the call of the gospel and lived out in different ways and settings. Here, we will consider, first, the beginnings of the monastic movement; then, the various different ways it developed; and finally how 'new monasticism' has taken shape within it (Christie and Flanagan 2020).

\section{The Fourth Century}

The distinction of being the first monk goes to an Egyptian called Isaac. The texts state that he was travelling along a road near the village of Karanis in north Egypt with a deacon called Antoninus in the year 324 when they met a fellow-traveller called Aurelius who was being attacked by robbers. They helped and cared for him. This event is reported in a contemporary chronicle and the use of this suggests that Isaac, as a monk, had a recognised place in the church, alongside priests and deacons (Judge 1977).

The word monk or monachos is derived from the Greek monos, which has various shades of meaning to do with singleness-alone, forsaken, unique, bereft or solitary. It has been used, from the 4 th century, to describe those who chose to dedicate themselves in a single-minded way to a life of prayer.

At the time when Isaac carried out his act of compassion for the traveller, in 324, the ascetic, Anthony, was attracting visitors and followers to a mountain in the east of Egypt. He was over 70 years old and he was to live a further 35 years. He had lived an eremitic 
form of ascetic life in a tomb near his village for forty years, then had travelled with a group of camel traders into more remote parts of the desert. Here, he had settled at the foot of a mountain called Clysma where he remained until his death at the age of 105 . His life was written by Athanasius who described Anthony's influence and writes that he 'persuaded many to take up the solitary life. So from then on there were many monasteries in the mountains and the desert was made into a city by the monks'. (Life of Antony 14). Many of those who followed this way of monastic or solitary living settled in the desert south of Alexandria, where the settlements of Nitria and Cellia became home to ascetics who followed a solitary life of struggle (Chitty 1966).

This way of life could be followed by those living in community as well as those living alone. About the same time, a soldier called Pachomius had been briefly in prison, where he had received the support of local Christians. When he was discharged from the army and was baptised, he determined to follow the faith of those who had cared for him. He settled in Upper Egypt, and he too lived a life of asceticism. Disciples joined him and eventually a network of communities grew up (Life of Pachomius. 1980; Rousseau 1995). Unlike the informal settlements of hermits in the north, Pachomius' communities were large and carefully regulated. They provided a secure if simple way of life for hard-pressed peasants who lived, worked, worshipped and studied together. They became known as coenobia, a word derived from the Greek, meaning common life.

There were further examples of ascetic living in other parts of the Christian world. Julian Saba, meaning the Old Man, came from Osrhoene in eastern Syria and was becoming known for his ascetic life. By the time of his death in 367 he was the centre of a community of a hundred followers (Theodoret. 1985). Syria became known for its extreme and unconventional forms of ascetic life. Stylites spent long periods living on the top of pillars, while boskoi or grazers led a wandering life living off wild plants. Some ascetic practices were seen as subversive and heretical, and became causes of scandal. These became known as Messalians, or those who prayed. A church council was convened at Gangra some time before 341 which legislated against these socially subversive practices, such as the cases of women who deserted their husbands and dressed in male clothes, and slaves who used their ascetic commitment as an excuse to leave their masters. Messalians were also accused of avoiding regular worship in church, preferring solitary prayer and their own assemblies (Stewart 1991). These various forms of life are a reminder that monastic life, and Christian discipleship, does not conform to the standards and values of secular society, and should always challenge and disturb.

Ascetic communities could be set up in cities as well as in desert. The career of Basil who later became bishop of Caesarea, often known simply as Basil the Great, shows how asceticism could adapt to urban life. Basil was born in 330 and as a young man he studied under philosophers in Constantinople and Athens. He also went to Egypt, Syria and Mesopotamia to visit the ascetics, and these lives made a deep impression on him. When he returned home to Pontus in Asia Minor he settled on his family estate where he lived a secluded philosophical life. Later, when he became bishop of Caesarea in 370, he drew on these mixed influences and founded a set of buildings which were known as the Basileiados, at the edge of the city. This was both a place where the ascetic life could be lived and also where the sick and needy could be cared for. Thus he adapted the ascetic life he had seen in Egypt and Syria so that it became become part of the ministry of the church in his city diocese. Basil preferred the name of spoudaioi, or the zealous, rather than monks, for the members of his community, so showing that he considered the monastic life as a normal way of life for those seeking deeper commitment (Binns 2020; Rousseau 1994).

The context for these new movements was a newly acquired freedom for the church. Before he went into battle against his rival Maxentius at the Milvian Bridge, the Emperor Constantine saw a vision of a cross in the heavens with the words 'in this sign conquer' (Eusebius. Life of Constantine 1.28). This led to his decision to become Christian and to the adoption of a new official policy of toleration for all religions (Eusebius, Church History 10.5; Ehrman 2018, pp. 219-21). This marked the ending of state persecution of the Christian 
church and the dawn of an era in which Christianity was to become the faith of the Roman empire. So now martyrdom, in the form of the acceptance of death for the faith, which had been the way of demonstrating true witness, ceased to be part of Christian experience (Binns 2020). In this new state of freedom and toleration, the movement of monasticism took root and grew within the church.

\section{Beginnings}

This survey of the eastern Mediterranean at the time when the church was changing its position from an embattled and persecuted minority to become the established faith of the empire shows that at this point of the history of the church, the ascetic life was a familiar if demanding form of discipleship. Just as the martyrs had been an example of courage and faith during the persecutions so now it was the ascetics who were becoming the heroes of the faith, impressing believers and attracting visitors. It was a time of change for the church as it emerged from its dark time of persecution and found itself becoming secure and influential. The challenge of martyrdom had been taken away, and those who longed for a radical way to show their faith and love had to find new pathways. These pathways led into the desert. An example of this movement is early Palestinian monk Chariton, who had been imprisoned during a time of persecution, then, on his release, travelled to the Holy City of Jerusalem and settled in a cave which became the centre of a group of monasteries. He exchanged the martyr's prison for the monk's cell (Life of Chariton. 1941).

The roots of asceticism are in the Bible, and were also there in the culture of the time. There were three influences which motivated the early ascetics, which we can refer to as Place, Purpose and Procedure. These all gave a shape and direction to this radical form of discipleship.

The Place for ascetics was the desert. In Greek this was the eremos topos or desert place and so those who lived there became known as hermits. In Palestine, city and desert were close. For those who lived in Jerusalem, a short walk over the ridge of the Mount of Olives to the east of the city took them into a wilder and drier terrain. The olive trees and vineyards of a Mediterranean environment and soil type quickly give way to more barren landscape like that of the central Asian steppe which leads to an African true desert as the Dead Sea becomes closer. Suddenly the city had become distant (Binns 1994, pp. 1002). The desert was a place of contrast to the city. Here, God could be experienced and encountered. It was in the desert that the Israelites found refuge from their slavery in Egypt and the saving presence of God, where they received the commandments on Mount Sinai. It was also the place where alternative forms of faith-in this case the worship of the idol of a golden calf-were challenged and rejected. Successive prophets from Elijah to John the Baptist went to the desert to find and preach a purer faith. Then, Jesus went into the desert at the start of his ministry, an example which successive monks followed. The desert was a physical expression of the call to change and to repent. It was a reminder that the Kingdom of God is not of this world but stands as a judgment against human sin. As the church extended, the nature of the desert changed. In Egypt desert was the dry land which began where the fertile Nile valley ended. In Syria it was the hill tops which overlooked the valleys below. Later in Russia it was the frozen forests of the north. Desert adapted to the geography of the land but remained as the place where the ascetic went to turn away from the city and towards God.

The Purpose of ascetic life was a single-minded turning towards God. Celibacy was just one aspect of this. In the New Testament, some passages teach a lifelong and faithful marriage relationship as ordered by God, but others commend celibacy and continence as a better way. 'Not everyone can accept this teaching but only those to whom it is given, for there are those who are eunuchs from birth, there are those who have been made eunuchs by others, and there are those who have made themselves eunuchs for the sake of the Kingdom of Heaven' (Matt 19.11-12). Passages like this should not be seen as a negative rejection of marriage and sexuality but rather as a positive search for what is most necessary. 
The true nature and meaning of celibacy is made clear through the words used in Syria. The word for single-which later became the Syrian equivalent of monk-was ihidaya. This is a word with a rich and suggestive set of meanings. It could refer to Christ who is the Only-Begotten Son. Or to the One God, to the first man Adam, to Christ as the second Adam, and then it could extend to those who shared in the life of the only-begotten Christ though baptism. There is a theological and scriptural background to the word ihidaya, which came to be used in several ways. It could be singular or unique; it could be single minded and not divided in heart; it could mean single as unmarried or celibate (Brock 1985, pp. 133-39; Peters 2018).

Among the Procedures, or disciplines, of ascetic living was fasting. Fasting is more than an act of self-denial. Eating is essential to life, and feasting is an image which evokes the kingdom of heaven, where food and drink are abundantly — even over-abundantlyprovided to thousands of people at the end of the day or at a wedding day, where the inclusion of tax collectors and sinners as guests at the feast define the universality of the gospel message. We should recognise that fasting is a way of eating-rather than not eating. Fasting could be an expression of penitence and so Christians fasted in the season before Easter. It was also a discipline and form of eating which nurtured the soul and spirit. Then, fasting expressed faith and longing for that eschatological banquet of heaven. Fasting rules could also give identity to a community. The Didache, probably written in the late first century, instructs Christians to fast on Wednesdays and Fridays-to distinguish themselves from the 'hypocrites' (here the author means the Jews) who fasted on Mondays and Thursdays (Didache 166). Later, the list of foods to be avoided in fasting seasons and the dates of the fasts were to become closely regulated, especially in the eastern churches.

The New Testament is a call to repent and believe the gospel. The longing for a radical discipleship took shape in a way of life which was located in a specific place, had a clear purpose and objective and a disciplined way of life to achieve this. It was a radical form of discipleship, living out the call to repent, recognising the presence of the kingdom of heaven in our midst, welcoming the promise of new life and building community in which the transformative power of grace would become experienced. It was a whole-hearted living out of the gospel.

\section{Varieties}

By the end of the fourth century monks were recognised as a distinct group or order within the church. The movement had a name and would develop an identity, a literature, a distinctive way of life and worship, and so find its place in the church (Binns 2002).

Travel was now easier for Christians and so people were able to communicate better. The monks received pilgrims and guests, and the settlements in Egypt, Syria and Palestine became popular visitor attractions. After staying to see and talk with the monks, the visitors took the ideas and practices back to their homes and there they introduced this new way of monasticism. Some visitors recorded their experiences in travel diaries and accounts of their meetings (Lives of the Desert Fathers 1980). So a monastic literary tradition was shaped and shared. It included accounts of the lives of the saints. The first of these, Athanasius' Life of Antony, is more than a biography (Athanasius. 1980). It presents an ideal to be followed which is a new form of martyrdom, and Antony is a full and perfect model human being. A case can be made that this book was the most widely copied and distributed book in the history of Christianity after the Bible, and spread the monastic ideal across the Christian world, including western Europe. It initiated a form of writing known as hagiography. The visitors also valued the sayings or collections of proverbs, sayings and stories, known as Apophthegmata (Sayings of the Desert Fathers 1975).

There were also monastic Rules attributed to founders such as Pachomius and Basil. These Rules were not systematic sets of regulations to govern all aspects of community life but rather were collections of letters, biblical commentary and advice. They were sources for each monastery to set out its own regulations. The monastic regulation was the typikon, giving a pattern of worship and making arrangements for practical details such 
as the way to choose a superior. The typikon of a large monastery was followed by other houses and some, like that of the monastery of Evergetis in Constantinople were widely imitated (Mullett and Kirby 1994; Hatlie 2007). The worship at the monastery of Mar Saba in Palestine for example became a model for others, and the monasteries of Studium and Evergetis in Constantinople looked to its practice as an example of how to recite the psalms. The liturgical style of the Palestinian desert came to be used in Constantinople and then through the wider church, contributing to the formation of Orthodox liturgy.

The monastic movement became integrated into the life of the church. The Council of Chalcedon in 451 enacted nine canons to regulate the monasteries. These stated that monks were to be under the jurisdiction of bishops who were responsible for the foundation and upkeep of monasteries. The growth in the number of monasteries in later centuries made this difficult to enforce. Nevertheless, it set out the principle that monks belonged within the church and were under the direction of the bishop. This connection was strengthened as monks were called on to become bishops. An early monk-bishop was Rabbula, who became bishop of Edessa in 412 and remained until his death in 436 . He maintained his ascetic disciplines throughout his episcopate, ands wanted his priests to be as 'similar to the heavenly angels as human nature allowed' (Sterk 2004). The practice of requiring bishops to be celibate and make monastic vows grew. Soon after the end of the controversy over icons in 843 when monastic leaders, and their arguments in favour of the veneration of icons had prevailed, a council at Haghia Sophia in Constantinople decided that all bishops should be celibate. Then, in 1186 another council required all bishops to take monastic vows, a situation which set in place a tradition which has persisted (Binns 2020, pp. 75-77).

Monasticism is a way of life and a form of radical Christian living. It has a title and name, an example set by monastic founders and saints, a literature which led to a theology of Christian living, a structure to guide the setting up of houses and communities. The monasteries became centres of church life. They were at the forefront of mission, houses of scholarship, places of inner prayer and public worship.

Monasticism in the western Catholic part of the church took a different direction from monasticism in the east. This happened as a result of the work of two monks, both called Benedict (Louth 2007, pp. 101-8). Benedict of Nursia (c 480-543) lived as a hermit on Mount Subiaco near Rome. His way of life changed when he was asked by a group of monks to become their leader or abbot, and this led him to follow a community rather than a solitary life. He founded twelve monasteries on the hills of central Italy with a monastery on Monte Cassino as the main house, and showed them how to order their lives in a disciplined and achievable way. He provided clear directions in his Rule which became the founding document of western monasticism. His Rule recognised four kinds of monks. Benedict approved of two of these classes-hermits living a solitary life and monks who were members of communities. However, he warned against the two less structured forms of life-monks following their own discipline in small domestic houses, which he called Sarabaites, and those who travelled with no settled home, which he called gyrovagi (Benedict. 1990, p. 1). The Rule of Benedict was used by the other Benedict—Benedict of Aniane (747-821). This Benedict used the Rule in monasteries which he founded and he persuaded the king Louis the Pious to do the same. Church Councils at Aachen in 816 and 817 decreed that all monasteries in the western empire should follow the Rule of Benedict. This led to the development of the monastic tradition in the west when the setting up of new orders, with a clear rule governing liturgical observance, life style, and even the dress, of members became a requirement. New orders continued to be founded, responding to changing social conditions, the needs of the church's mission and the impact of saintly monastic founders. Each order had its own character and structure, its governance and discipline, which marked it out from others. Monasticism in the west had changed from being a broad movement into becoming an institution (Evans 2016).

These different directions within the one tradition between the east and west show how monastic life could develop in various ways. Across the Christian world, monks adapted their lives to fit into the environment and to respond to the needs of the church 
and the society in which they found themselves. From the 4 th century onwards, the church spread across Syria and Persia, as far east as India and China, south into Nubia and Ethiopia, and north into central Europe and the Balkans, and, after 1000, across Russia. In large cities like Constantinople there were large and well-endowed houses; in rural areas monasteries were agricultural and industrial enterprises offering employment and security to peasants in uncertain times. Some monks explored less inhabited places and found remote and inhospitable places to settle, being drawn to islands, mountains, deserts and forests, often in places where the Christian faith had not yet been preached. Meanwhile others stayed where they were and converted their home into a monastery where family members and others joined to live a devout life. Now, with the name of monk to designate them, a hagiography and literature of the desert to guide them, a place in the church, monasticism was a broad, free but identifiable movement which brought renewal and life.

Within this widely dispersed and flexible approach to ascetic living, the founders of major monasteries had a lasting influence in shaping the monastic tradition, which provided guidance, teaching and leadership for the church. The lives and examples of some of the influential monastic saints show how the tradition developed and gives a summary of the nature of the monastic vocation.

Antony (c 251-356), the Father of Monks, lived as a hermit, with a relationship with God in prayer as the sole purpose and meaning of his life.

Pachomius (c 290-346), formed coenobia or communities as places in which this ascetic life could be lived and regulated, and so made the life more accessible and open.

Basil the Great (330-379) affirmed that charity is the motivation of monastic life and so integrated communities into the life of the wider church.

Benedict (c 480-c 560), known as the Father of Western Monasticism, drew up a Rule for a balanced way of life which provided a carefully regulated structure and discipline which became normative for western monasticism.

Athanasius (c 920-1003) established the monastery of the Great Lavra on Mount Athos which was one of several monastic mountains in the Byzantine East and has remained as an international centre of monastic life, liturgy and culture in the Orthodox East.

Sergius of Radonezh (1314-1392) and his followers extended monastic life into the far north of Russia, showing that monastic life always seeks out remote and inhospitable places, and so giving a missional character. Meanwhile Tekla Haymonot (c 1215-c1313) had earlier spread monastic life to the south, across Ethiopia, where the tradition remains strong.

Gregory Palamas (c 1296-1359) taught the practice of hesychasm through the use of the Jesus Prayer which provided a clearly defined and articulated theology of monastic life.

By the time that the Reformation in the west and the Fall of Constantinople to the Ottoman Turks (1453) led to the disruption and closure of many monasteries, the tradition and way of life of monasticism had become established across the Christian world.

\section{A New Monasticism}

A way of life which developed in the first millennium has shown itself resilient ad led to revival and new forms of life in the modern era. Many new communities have discovered that the monastic tradition has provided resources for discerning their vocation and a place in the life of the church.

Writings and practices from earlier periods can have a surprising freshness and relevance in our own day. This has been vividly shown by the publishing history of an ancient text which has had an unexpected revival in popularity. The Philokalia, meaning love of the beautiful, is an anthology of texts on inner prayer. The collection was made by two monks on Mount Athos, Nicodemus and Macarius, in the course of the 18th century and published in Venice in 1782. It consists of writing by around thirty-six authors who lived between the 4 th and 15th centuries, and covers a wide range of ascetical themes. It forms a full and authoritative summary of the insights and teachings of generations of monks (Bingaman and Nassif 2012). Its publication history shows how the vision of 
the monastic vocation has been followed through the history of the church and still gives direction and meaning to radical forms of Christian living. Although there was a similar collection issued in Russia which was widely read, the Greek volume aroused little interest when it was published and there were no further editions during the following century. However, there has been an unexpected revival of enthusiasm for this extensive anthology. This is shown in a rush of new translations-into modern Greek in 1957, into Romanian with a series of volumes from 1946 until 1991, and English from 1979 to 1995, and also into other languages. The success of these editions led the English translator, Kallistos Ware, to comment that 'it is surely astonishing that a collection of spiritual texts originally intended for Greeks living under Ottoman rule should have achieved its main impact two centuries later in the secularised and post-Christian west' (Ware 2012, p. 34). He called it a spiritual time bomb. This publishing phenomenon is one sign of the continuing importance of the monastic tradition for the church.

This renewed interest in medieval monastic literature shows that the ideas and practices of monasticism still can inspire and influence in modern society. A part of the Reformation movement in western Europe had been a reaction against the western from of monasticism. In England, a swift and complete closure of monasteries and priories took place in five years between 1536 and 1541. Other expressions of a radical discipleship took the place of monastic ideals but in the last century monastic ideals have been rediscovered by various parts of the church (Teasdale 2002; Okholm 2007).

Among those who looked to the monks for guidance was the German Lutheran theologian and pastor, Dietrich Bonhoeffer, who was executed by the Nazis at the age of 39 in 1945 . He wrote in 1935 that 'the restoration of the church will surely come only from a new type of monasticism which has nothing in common with the old but a complete lack of compromise in a life lived in accordance with the Sermon on the Mount in the discipleship of Christ. It is high time that people banded together to do this' (Bonhoeffer [1939] 1954; Peters 2013). These words showed how the tradition of monasticism has passed on a style of Christian living which has retained faithfulness to the gospel message. His words have been discussed and reflected on by others and have encouraged the emergence of a 'new monasticism'.

Jonathan R. Wilson was a Baptist theologian teaching in Vancouver in Canada who developed the idea of a new monasticism in several editions of an essay which he called Faithful Living in a Fragmented World (Wilson 2010). He diagnosed the state of contemporary society as fragmented, since the medieval vision of a universal church and the Enlightenment optimism of a rational civilisation have both been lost in a post-modern and post-Christian society. He developed the suggestions of Bonhoeffer and others to offer the hope for Christian communities which would live out the gospel message in a faithful and integrated way, rooted in the tradition of faith and so be a witness and transforming power of the Christian faith.

His ideas were the subject of a meeting held in 2003 when members of several communities met together to share their experiences and ideals. Out of this meeting came a declaration of twelve principles of a new monasticism which could be the basis of a new form of common life (Rutba 2005).

These are:

1. Relocation to the "abandoned places of Empire" [at the margins of society, usually in depressed, urban areas]

2. Sharing economic resources with fellow community members and the needy among us

3. Hospitality to the stranger

4. Lament for racial divisions within the church and our communities combined with the active pursuit of a just reconciliation

5. Humble submission to Christ's body, the Church

6. Intentional formation in the way of Christ and the rule of the community along the lines of the old novitiate 
7. Nurturing common life among members of an intentional community

8. Support for celibate singles alongside monogamous married couples and their children

9. Geographical proximity to community members who share a common rule of life

10. Care for the plot of God's earth given to us along with support of our local economies

11. Peacemaking in the midst of violence and conflict resolution within communities along the lines of Matthew 18

12. Commitment to a disciplined, contemplative life

These twelve principles show how the practices of the early monks, and the rules of later orders, have been developed into guidance for new forms of monastic life. They are faithful to the roots in the ascetic lives of the early monks, recognise that they belong within the continuing monastic tradition but respond to the needs and preoccupations of contemporary society.

So there is still a desert but it is to be found on the margins and among the dispossessed, which are spoken here as 'the abandoned places of Empire'. Deserts are places where the security and prosperity of modern society has broken down, and where life is insecure and fragile. There is still a value given to celibacy which has again become an expression of a single-minded life directed towards God. Those who choose to live a celibate life are valued and supported, but a married relationship can have that same quality of singlemindedness. Then, fasting has been given a wider meaning. It is expressed within a wider spiritual discipline. New monastics often describe their life as intentional to show how their discipline and contemplation guide the life of the community.

While new monastics find how to affirm traditional monasticism, they also place it firmly in modern society. So the twelve principles speak of a concern for the care of the natural world and awareness of the environmental crisis; the witness to reconciliation in places of conflict; the call for justice and dignity for all people of different races; and a sharing of goods in a unequal society divided by wealth and exploitation.

The new monastic movement has become a movement of renewal and mission in the church which has had a wide influence. Communities which see themselves as part of this movement show the creativity and adaptability of the monastic tradition which has come to be lived out in varied settings today, as it was in the 4th century (Cray et al. 2010). These communities are not restricted to those living together but include visitors and those who live apart but follow the same style of faith. So numbers who live within the community fluctuate and their influence is widely dispersed.

Jonathan Wilson's daughter Leah married another Jonathon, and together the WilsonHartgroves founded the Rutba community house in North Carolina-named after a town in Iraq where members of their Christian Peacemaker Team had received medical care after a car accident (Wilson-Hartgrove 2005). Like Pachomius before them, they were struck by this example of care and set up Rutba House to be a place of hospitality where all would be welcomed. This rule of hospitality and welcome led to the meeting which formulated the 12 principles of the new monasticism.

Communities have become centres of faith, welcoming visitors in pilgrimage and being a place for meeting and engagement. The community at Taizé traces its beginnings to 1940 when a Frenchman Roger Schütz, at the age of 25 and recently recovered from tuberculosis, bought a cottage in the village where he welcomed and sheltered refugees fleeing the violence of the Second World War. He continued this work with the help of his sister Genevieve both at Taizé and, for a while at Geneva, and then others came to join him. In 1949 Brother Roger and six others made lifelong vows, and in 1953 Brother Roger wrote the Taizé Rule. Since then the community, with brothers from various churches and countries, has provided a welcome to all who came and developed a distinctive style of worship based around repetitive and meditative chants. It receives many visitors and its influence has spread throughout the world. Brother Roger himself was stabbed and killed during evening worship by a mentally ill visitor in 2005 but the community has continued its ministry and growth. Later, a monastery was founded at Bose in northern Italy on 
the last day of the Second Vatican Council in December 1965 by Enzo Bianchi, which included members of various evangelical churches within the community. The presence of non-Catholics is a reason for concern within the Vatican which led to the suspension of all services between 1967 and 1968, and a continuing uneasy relationship with the church authorities. This tension shows the creativity and radicality of monasticism which can challenge church as well as secular society (Palmisano 2016).

The Northumbria Community in the UK was set up by a Baptist minister, Roy Searle, and Scottish episcopalian, John Skinner. It grew gradually through the 1980s and was established in 1989. After several moves it is now based in Northumberland at Nether Springs Farm, near to the island of Lindisfarne. Here, the monk and bishop Cuthbert (634-687) had lived and the island was a centre of Celtic spirituality with its monastic, pilgrimage traditions. Its members describe themselves as a dispersed community, and encourage each other to share in a rule built around the principles of availability and vulnerability, and to pray using Celtic forms of worship and spirituality.

A modern form of urban desert was discovered and inhabited by the Simple Way community. In 1995 several homeless families had moved into an empty building owned by the Catholic Church in Kensington North Philadelphia. When they were threatened with eviction, a group of students led by Shane Claiborne moved in with them, and what had started as a two-day protest against the threatened eviction by the church authorities developed into a settlement which continued for three years. Then, in 1997, members of the community bought a disused shoe repair shop and continued their shared community life. They drew inspiration from several sources, some visited Mother Teresa in Calcutta and lived in a leper colony. Simple Way grew from one to six houses, and has set up several projects in their deprived neighbourhood, growing vegetables, distributing food, setting up new jobs and businesses. Another example of seeking out a contemporary desert is the Monastery wing of form of desert is a wing of Kumla high security prison in Sweden, set up by a Jesuit priest and Lutheran pastor, where prisoners can go to work through the Ignatian spiritual exercises as a way of addressing their underlying personal issues (Sizoo 2004, 2010).

The new monasticism has also become a support to mission. Since monks have sought inhospitable and desert places, there was a spiritual dynamic which drove them to new places and unfamiliar - even hostile cultures. So in settings as diverse as medieval Ethiopia or 19th century Asia, monks often preceded the armies of the Christian kingdom of Ethiopia or imperial Russia to form places where the Christian life was practised and taught. It has been commented that as Christian kingdoms set out to conquer new places, armies set up government but monasteries brought civilisation. The longing of monks to bring the gospel to places or cultures where it is not known has led evangelicals to find resources and models for mission from within the monastic tradition. In the city of Sheffield in the UK, the combined Anglican and Baptist congregations of St Thomas Church at Crookes decided on a new mission initiative. They rented a space in the centre of the city and began a new place and form of worship which run simultaneously with worship at their parish church. This was part of a wider movement of mission and evangelism which led to them setting up the Order of Mission in April 2003. It developed a rule based on the principles of Purity, Accountability and Simplicity. Within three years the Order had over 200 members and has groups in many parts of the world. So it has become an international missionary order within this new Monasticism.

These stories come from different countries, different church traditions and have their own charisms and gifts. Each shows how the tradition of the monks can be expressed and lived in fresh and contemporary ways. Like the ascetic communities of the peace of the church in the 4th century, they bring a life formed by a radical discipleship which is lived out in the time and place to which they are called. 


\section{Conclusions}

The monastic journey of the first monk Antony began when, as a young man of 18, he heard the gospel read one Sunday in church with the instruction 'if you would be perfect, sell what you possess and give to the poor and you will have treasure in heaven'. He went home and sold his family lands and possessions. So his life as a monk began when he listened to the word of God in scripture with its call to perfection and then responded with whole hearted generosity.

The rich tradition of monasticism was created by the single-minded discipleship, the willingness to listen to the call to discipleship and the creative response to the needs of the society of the time. Monasticism has therefore been both old, in being faithful to ancient traditions, and new, in engaging with the challenges of the age. The long story of monastic living, while rooted in the gospel message, is a series of fresh initiatives and renewed revivals.

New monastics belong within this tradition. They draw on the resources of those who have gone before them while challenging fixed ideas and being ready to embrace unexpected and risky ways of life.

Like Antony and like countless others they seek to hear the message of the gospel and to respond, single-mindedly and whole-heartedly, to the abundant promise of life and the call to a radical discipleship.

Funding: This research received no external funding.

Conflicts of Interest: The author declares no conflict of interest.

\section{References}

\section{Primary Sources}

Athanasius. 1980. Life of Antony. Translated by Robert Gregg. Classics of Western Spirituality. London: SPCK.

Benedict. 1990. Rule of Benedict. Translated by Abbot Parry. Leominster: Gracewing.

Didache. 2010. The Didache. Translated by Thomas O'Loughlin. London: SPCK.

Eusebius. 1927. Ecclesiastical History. Translated by H. Lawlor and J. Oulton. London: SPCK.

Eusebius. 1979. Life of Constantine. Translated by Henry Wace and Philip Schaff. Library of Nicene and Post-Nicene Fathers vol 1. Grand Rapids, MI: Christian Classics Etheral Library.

Life of Chariton. 1941. Edited by Gerard Garitte. Rome: Bulletin de l'Institut Historique Belge de Rome. pp. 5-50.

Life of Pachomius. 1980. Translated by Armand Veilleux. Pachomian Koinonia vol 1 The Life of Pachomius and His Disciples. Kalamazoo: Cistercian Publications.

Lives of the Desert Fathers. 1980. Translated by Norman Russell. London and Oxford: Mowbray.

Philokalia. 1979-1995. Translated by Geoffrey Palmer, Philip Sherrard and Kallistos Ware. London: Faber.

Rufinus The Church History of Rufinus of Aquileia, Books 10-11a. Translated by P. Armidon. Oxford: Oxford University Press.

Sayings of the Desert Fathers. 1975. Translated by Benedicta Ward. London and Oxford: Mowbray.

Sozomen. 1960. Ecclesiastical History. Edited by Joseph Bidez. Die greichischen christlichen Schriftsteller der ersten Jahrhunderte. Berlin: Akademie-Verlag.

Theodoret. 1985. History of the Monks of Syria. Translated Richard Price. Kalamazoo: Cistercian Press.

\section{Secondary Sources}

Bingaman, Brock, and Bradley Nassif. 2012. The Philokalia, A Classic Text of Orthodox Spirituality. Oxford: Oxford University Press. Binns, John. 1994. Ascetics and Ambassadors of Christ: The Monasteries of Palestine 314-631. Oxford: Oxford University Press.

Binns, John. 2002. An Introduction to the Christian Orthodox Churches. Cambridge: Cambridge University Press.

Binns, John. 2020. The T E T Clark History of Monasticism. The Eastern Tradition. London: T \& T Clark.

Bonhoeffer, Dietrich. 1954. Life Together. Translated by John Doberstein. New York: Macmillan. First published 1939.

Brock, Sebastian. 1985. The Luminous Eye: The Spiritual World of Saint Isaac the Syrian. Kalamazoo: Cistercian Publications.

Chitty, Derwas. 1966. The Desert A City. Oxford: Mowbrays.

Christie, Douglas, and Bernadette Flanagan. 2020. The Oxford Handbook of Christian Monasticism. Edited by Kaczynski Bernice. Oxford: Oxford University Press, pp. 634-44.

Cray, Graham, Ian Mobsby, and Aaron Kennedy, eds. 2010. New Monasticism as Fresh Expressions of Church. Norwich: Canterbury Press. Ehrman, Bart D. 2018. The Triumph of Christianity. London: Oneworld.

Evans, Gillian. 2016. The I B Tauris History of Monasticism The Western Tradition. London: I B Tauris.

Hatlie, Peter. 2007. The Monks and Monasteries of Constantinople ca 350-850. Cambridge: Cambridge University Press. 
Judge, E. A. 1977. The Earliest Use of the word "Monachos" for Monk (P. Coll. Youtie 77) and the Origins of Monasticism. Jahrbuch für Antike und Christentum 20: 72-89.

Louth, Andrew. 2007. Greek East and Latin West. New York: St Vladimir's Seminary Press.

Mullett, Margaret, and Anthony Kirby, eds. 1994. The Theotokos Evergetis and Eleventh Century Monasticism. Papers of the Third Belfast Byzantine International Colloquium, 1-4 May 1992. Belfast Byzantine Texts and Translations 6. Belfast: Belfast Byzantine Enterprises.

Okholm, Dennis. 2007. Monk Habits for Everyday People, Benedictine Spirituality for Protestants. Ada: Brazos Press.

Palmisano, Stefania. 2016. Exploring New Monastic Communities: The Re(invention) of Tradition. Abingdon: Routledge.

Peters, Greg. 2013. Reforming the Monastery, Protestant Theologies of the Religiouis Life. Eugene: Cascade.

Peters, Greg. 2018. The Monkhood of All Believers, the Monastic Foundation of Christian Spirituality. Ada: Baker Academic.

Rousseau, Philip. 1995. Pachomius. Berkeley: University of California Press.

Rousseau, Philip. 1994. Basil of Caesarea. Berkeley: University of California Press.

Rutba, House. 2005. School(s) for Conversion. 12 Marks for a New Monasticism. Eugene: Cascade.

Sizoo, Lysanne. 2004. When Cell Doors and Hearts Open. The Way 43: 161-68.

Sizoo, Lysanne. 2010. Kumla Prison Monastery: Taking the Next Step. The Way 49: 93-104.

Sterk, Andrea. 2004. Renouncing the World yet Leading the Church. The Monk Bishop in Late Antiquity. Harvard: Harvard University Press. Stewart, Columba. 1991. Working the Earth of the Heart. Oxford: Oxford University Press.

Teasdale, Wayne. 2002. A Monk in the World: Cultivating a Spiritual Life. Novato: New World Library.

Ware, Kallistos. 2012. St Nikodimos and the Philokalia. In The Philokalia. Edited by Bingaman Brock and Bradley Nassif. Oxford: Oxford University Press, pp. 9-35.

Wilson, Jonathan. R. 2010. Living Faithfully in a Fragment World. Eugene: Cascade.

Wilson-Hartgrove, Jonathan. 2005. To Baghdad and Beyond: How I Got Born Again in Babylon. Eugene: Wipf and Stock. 